\title{
PROFITABILITAS MEMODERASI FINANCIAL LEVERAGE DAN PERTUMBUHAN PERUSAHAAN TERHADAP PERATAAN LABA
}

\author{
INDAWATI ${ }^{1}$, ANGGUN ANGGRAINI \\ Prodi Akuntansi S1, Fakultas Ekonomi, Universitas Pamulang \\ *Email: dosen02151@unpam.ac.id
}

\begin{abstract}
The purpose of this study is to determine and analyze the effect of Profitability Moderating Financial Leverage and Company Growth partially and together on Income Smoothing. The research method used in this study is a quantitative method. Data taken is secondary data from manufacturing companies listed on the IDX. Based on the results of the study, the following findings are found: The Effect of Financial Leverage based on Return On Assets (ROA) on income smoothing from research results Provides information that Financial Leverage based on Return on Assets (ROA) has a positive and significant effect on income smoothing (ROA) Income Smoothing). The influence of company growth based on Return On Asset Equity (ROE) on income smoothing based on the results of research that has been done can be concluded that company growth has a significant and significant effect on income smoothing, so if there is an increase in company growth then income smoothing will increase. The Effect of Financial Leverage on Profitability Moderated Profit Flattening It can be concluded that Financial Leverage and Company Profitability moderated Growth simultaneously influence Profit Smoothing. The effect of company growth on profit smoothing moderated by profitability, it can be concluded that company growth has significant and significant effect on income smoothing with moderated profitability. Effect of Financial Leverage, company growth which is moderated by profitability to income smoothing, it can be concluded that Financial Leverage and Company Growth which is moderated by Profitability have a simultaneous effect on Income Smoothing.
\end{abstract}

Keywords: profitability, financial leverage, income smoothing. 


\section{PENDAHULUAN}

Laporan keuangan merupakan salah satu informasi yang relevan. Laporan keuangan dapat mencerminkan kondisi perekonomian perusahaan, dimana informasi tersebut sangat berguna bagi pihak eksternal dan internal perusahaan. Laporan keuangan merupakan bentuk sarana untuk pertanggungjawaban tentang apa yang telah dilakukan atau dikerjakan oleh manajemen atas sumber daya pemilik.

Salah satu parameter yang digunanakan untuk mengukur kinerja manajemen adalah laba. Laba beserta komponennya yang terdapat dalam pelaporan keuangan dapat menunjukkan informasi suatu entitas bisnis mengenai prestasi yang diraihnya. Laba yang dilaporkan merupakan informasi yang berharga bagi pihak internal dan eksternal. Informasi laba dalam laporan keuangan bertujuan untuk menaksir risiko investasi atau meminjamkan dana, membantu mengestimasi kemampuan laba, dan menilai kinerja manajemen.

Hal ini sesuai dengan Pernyataan Standar Akuntansi (IAI, 2015) yang menyatakan bahwa informasi kinerja perusahaan, terutama profitabilitas, diperlukan untuk menilai perubahan potensial sumber daya ekonomi yang mungkin dikendalikan di masa depan. Informasi yang terkandung dalam laba bertujuan untuk mengetahui bagaimana kinerja dari manajemen apakah baik atau tidak, membantu memprediksi hasil laba di masa datang, dan memprediksi kemampuan perusahaan meminjam dana kepada investor.

Perhatian investor seringkali terpusat pada laba sehingga hal tersebut membuat manajemen terdorong untuk melakukan perilaku yang tidak semestinya (dysfunctional behavior). Pada umumnya, perhatian para pemakai laporan keuangan hanya berfokus pada laba yang terdapat dalam laporan laba rugi untuk menilai kinerja sebuah perusahaan yang digunakan untuk mengambil keputusan, Manajemen laba merupakan perilaku yang tidak semestinya dari manajemen. Bentuk dari manajemen laba yang kerap dilakukan oleh manajer adalah perataan laba. Berdasarkan latar belakang di atas, peneliti melakukan penelitian dengan Judul: "Profitabilitas Memoderasi Financial Leverage dan Pertumbuhan Perusahaan Terhadap Perataan Laba".

\section{LANDASAN TEORI DAN HIPOTESIS}

\subsection{Teori Keagenan}

Teori agen merupakan teori yang mengatur hubungan antara pemegang saham (principal) sebagai pemilik kepentingan dan manajemen (agent) sebagai pihak yang menjalankan kepentingan. Teori ini menjelaskan adanya konflik kepentingan yaitu perbedaan kepentingan antara manajemen dengan pemilik perusahaan, hubungan agensi muncul ketika satu orang atau lebih (principal) mempekerjakan orang lain (agent) untuk memberikan suatu jasa dan lalu mendelagasikan wewenang dalam menjalankan kepentingan kepada agen tersebut. 


\subsection{Perataan Laba (Income Smoothing)}

Menurut Belkaoui (2007:73) dalam Gantino (2015) perataan laba (income smoothing) adalah pengurangan fluktuasi laba dari tahun ke tahun dengan memindahkan pendapatan dari tahun-tahun yang tinggi pendapatannya ke periode-periode yang kurang menguntungkan.

Praktik perataan laba menyebabkan collapse-nya beberapa perusahaan internasional, Menurut Gosh (2010) dalam Febriyanti dkk (2014).

Manajemen laba menjadi salah satu bentuk keleluasaan yang diberikan SAK agar laba yang dilaporkan perusahaan sesuai dengan target yang ditetapkan sebelumnya. Target yang akan dicapai adalah target laba jangka panjang yang tumbuh dan berkesinambungan, sebagai representasi dari proses ekonomi normal.

Manajemen laba bukan sebuah kecurangan jika manajer tidak melaporkan penjualan fiktif, tidak melaporkan penjualan ketika produk-produk yang belum selesai ikut dikirimkan, mencatat secara cukup biaya-biaya, tidak melakukan transaksi barter dimana barang atau jasa dinilai overvalue atau undervalue, tidak melakukan penilaian aset yang lebih tinggi, dan tidak mengkapitalisasi biaya dengan tidak cermat.

\section{Tujuan Dilakukannya Perataan Laba}

Menurut Foster dalam penelitian Dwi mulyani dan Abraham, tujuan perataan laba adalah Memberikan informasi yang relevan dalam melakukan prediksi terhadap laba di masa yang akan datang, memprediksi citra perusahaan dimata pihak luar bahwa perusahaan tersebut memiliki resiko yang rendah, Meningkatkan persepsi pihak eksternal terhadap kemajuan manajemen, Meningkatkan kompensasi bagi pihak manajemen, Meningkatkan kepuasan relasi bisnis.

\section{Dimensi Perataan Laba}

Dimensi parataan laba pada dasarnya merupakan alat yang digunakan untuk menyelesaikan perataan angka pendapatan. Menurut Eckel yang didukung oleh Nesser dan Parulina, perataan laba dapat dibedakan menjadi dua jenis utama yaitu: Artificial Smoothing Yaitu perataan laba yang dilakukan melalui prosedur akuntansi yang diterapkan untuk memidahkan biaya atau pendapatan dari satu periode ke periode yang lain yaitu dengan mengubah kebijakan akuntansi, Real Smoothing Yaitu perataan laba yang dimanipulasi melalui transaksi nyata dengan mengatur (menunda atau mempercepat) transaksi.

\section{Objek Perataan Laba}

Sasaran dalam melakukan perataan laba dapat difokuskan pada aktivitas yang umumnya dilakukan oleh pihak manajemen untuk mempengaruhi aliran dana atau informasi. Artinya untuk menciptakan laporan keuangan yang diinginkan, manajemen dapat memasukkan informasi yang seharusnya dilaporkan pada periode yang telah lalu atau yang akan datang ke dalam laporan periode saat ini atau sebaliknya. Beberapa unsure dalam laporan keuangan yang sering kali 
dijadikan sasaran untuk melakukan perataan laba, diantaranya, unsur penjualan, unsur biaya.

Alasan Manajemen Melakukan Perataan Laba Menurut Hepworth dalam penelitian Nasser dan Parulina mengungkapkan bahwa manajer yang termotivasi untuk melakukan perataan laba karena ingin mendapatkan berbagai keuntungan ekonomis dan psikologis, yaitu, Mengurangi total pajak yang terutang, Meningkatkan kepercayaan diri manajer karena penghasilan yang stabil mendukung kebijakan deviden yang stabil, Mengingkatkan hubungan antar manajer dan karyawan karena pelaporan laba yang meningkat tajam member kemungkinan munculnya tuntutan kenaikan gaji dan upah, Siklus peningkatan dan penurunan penghasilan dapat ditandingkan dengan gelombang optimism dan pesimisme dapat diperlunak.

\subsection{Financial Leverage}

Financial leverage adalah penggunaan sumber dana yang memiliki beban tetap dengan harapan bahwa akan memberikan tambahan keuntungan yang lebih besar dari pada beban tetapnya sehingga akan meningkatkan keuntungan yang tersedia bagi pemegang saham. Financial Leverage timbul karena adanya kewajiban-kewajiban finansial yang sifatnya tetap (fixed financial charges) yang harus dikeluarkan oleh perusahaan. Kewajiban-kewajiban finansial yang tetap ini tidaklah berubah dengan adanya perubahan tingkat EBIT dan harus di bayar tanpa melihat sebesar apa pun tingkat EBIT yang dicapai perusahaan.

Kepekaan perubahan ini di ukur dengan derajat Financial Leverage (degree of financial leverage / DFL) yaitu persentase perubahan pendapatan per lembar saham (EPS) dibagi dengan persentase perubahan laba operasi (EBIT) serta financial leverage dapat di ukur dengan Leverage Factor yaitu perbandingan total hutang dengan total aktiva. Secara aljabar ditulis sebagai berikut

\section{Leverage Factor $=$ Total Debet $/$ Total Aset DFL = \% Perusahaan EPS / \% Perusahaan EBIT}

Apabila perusahaan menggunakan rencana $100 \%$ modal sendiri untuk membelanjakan usahanya, maka nilai DFL adalah satu untuk seluruh rencana laba operasi, nilai DFL yamg besar menunjukan bahwa perubahan tingkat EBIT akan menghasilkan perubahan yang besar pada laba bersih (EAT) atau pendapatan per lembar saham (EPS).

Rasio Leverage atau Rasio solvabilitas adalah rasio yang menunjukkan besarnya aktiva sebuah perusahaan yang didanai dengan utang, Rasio ini merupakan ukuran yang menunjukkan kemampuan perusahaan untuk membayar seluruh kewajibannya. Rasio-rasio solvabilitas digunakan untuk menggambarkan kemampuan perusahaan dalam membayar kewajiban jangka panjangnya, Rasio hutang yang biasa digunakan adalah debt ratio, times interest earned ratio, dan fixed-payment coverage ratio. 


\section{Debt Ratio $=\frac{\text { Total Liabilities }}{\text { Total Assets }}$}

Debt ratio mengukur proporsi dari total asset yang didanai oleh kreditor perusahaan. Semakin tinggi nilai debt ratio, semakin tinggi pula jumlah uang kreditor yang digunakan dalam menghasilkan laba.

\section{Debt to Equity = Total Liabilities \\ Shareholders Equity}

Debt-to-equity ratio adalah salah satu ukuran rasio solvabilitas yang akan digunakan dalam penelitian ini. Debt-to-equity ratio yang terlalu tinggi mengindikasikan hutang yang berlebihan.

Times interest earned ratio mengukur kemampuan perusahaan untuk membayar beban bunga hutang perusahaan. Rasio leverage adalah rasio yang digunakan untuk mengukur seberapa besar aktiva yang dimiliki perusahaan, dengan rasio ini dapat diketahui posisi perusahaan dan kewajibannya yang bersifat tetap kepada pihak lain serta keseimbangan nilai aktiva tetap dengan modal yang ada.

\subsection{Pertumbuhan Perusahaan}

Pertumbuhan perusahaan sangat diharapkan oleh pihak internal maupun eksternal perusahaan, karena pertumbuhan yang baik memberi tanda bagi perkembangan perusahaan. Dari sudut pandang investor, pertumbuhan suatu perusahaan merupakan tanda perusahaan memiliki aspek yang menguntungkan, dan investor pun akan mengharapkan tingkat pengembalian (rate of return) dari investasi yang dilakukan menunjukkan perkembangan yang baik.

\subsection{Profitabilitas}

Rasio Profitabilitas (Profitability Ratio) adalah rasio atau perbandingan untuk mengetahui kemampuan perusahaan untuk mendapatkan laba (profit) dari pendapatan (earning) terkait penjualan, aset, dan ekuitas berdasarkan dasar pengukuran tertentu, Jenis-jenis rasio profitabilitas.

Gross Profit Margin, mengukur efisiensi perhitungan harga pokok atau biaya produksi. Semakin besar gross profit margin semakin baik (efisien) kegiatan operasional perusahaan yang menunjukkan harga pokok penjualan lebih rendah dari pada penjualan (sales) yang berguna untuk audit operasional. Jika sebaliknya, maka perusahaan kurang baik dalam melakukan kegiatan operasional. Rumus perhitungan laba kotor sebagai berikut.

\section{Gros Profit Margin= (laba kotor/ total pendapatan) $\mathrm{x} 100 \%$}

Rasio ini mengukur laba bersih setelah pajak terhadap penjualan. Semakin tinggi Net profit margin semakin baik operasi suatu perusahaan. Net profit margin dihitung dengan rumus berikut ini. 
Net Profit Margin = Laba Bersih Setelah Pajak : Penjualan

Return On Asset Ratio, Tingkat pengembalian asset merupakan rasio profitabilitas untuk menilai persentase keuntungan (laba) yang diperoleh perusahaan terkait sumber daya atau total asset sehingga efisiensi suatu perusahaan dalam mengelola asetnya bisa terlihat dari persentase rasio ini. Rumus Rasio Pengembalian Aset sebagai berikut.

\section{ROA = Laba Bersih : Total Aset}

Return non Equity Ratio, merupakan rasio profitabilitas untuk menilai kemampuan perusahaan dalam menghasilkan laba dari investasi pemegang saham perusahaan tersebut yang dinyatakan dalam persentase.

\section{ROE = Laba Bersih setelah Pajak : Equitas Pemegang Saham}

Return non investment merupakan rasio profitabilitas yang dihitung dari laba bersih setelah dikurangi pajak terhadap total aktiva. Return non investment berguna untuk mengukur kemampuan perusahaan secara keseluruhan dalam menghasilkan keuntungan terhadap jumlah aktiva secara keseluruhan yang tersedia pada perusahaan. Semakin tinggi rasio ini berarti semakin baik kondisi suatu perusahaan. Rumus Return non Investment berikut ini.

\section{ROI= ( (Laba Atas Investasi - Investasi Awal) / Investasi )x $100 \%$}

\subsection{Kerangka Konseptual}

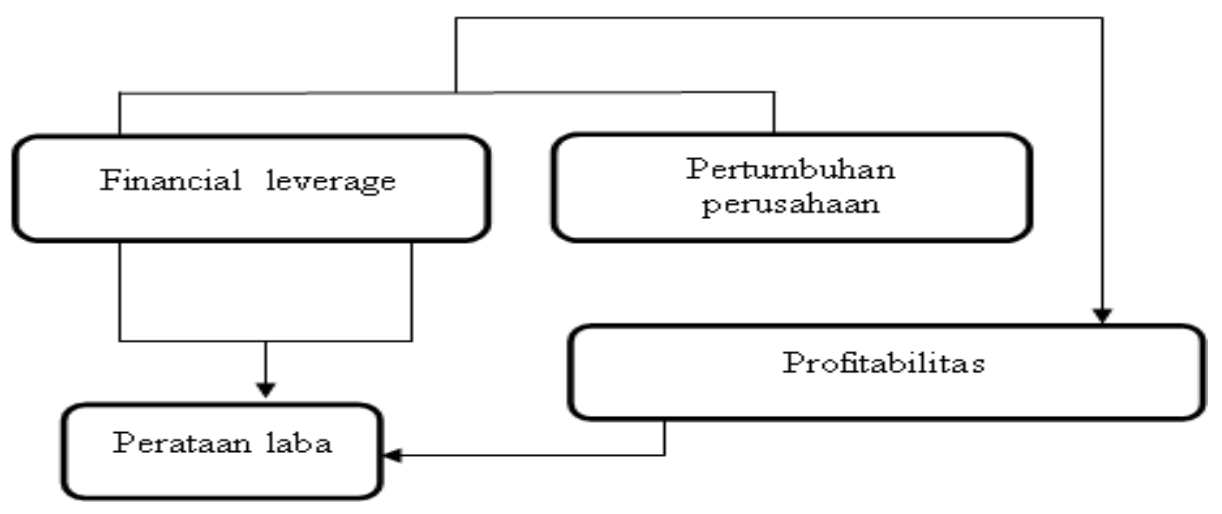

\subsection{Hipotesis Penelitian}

\subsubsection{Pengaruh Financial Leverage dan Pertumbuhan Perusahaan terhadap} Perataan Laba yang dimoderasi profitabilitas

. Profitabilitas merupakan ukuran penting untuk menilai sehat atau tidaknya perusahaan yang akan mempengaruhi investor dalam pengambilan keputusan. Sebagai alat ukur untuk profitabilitas ini, penulis menggunakan return on asset (ROA) yang dapat dihitung dengan membandingkan antara laba yang diperoleh dalam suatu periode dengan jumlah aktiva yang dimiliki olehperusahaan. Semakin 
tinggi profitabilitasperusahaan, maka akan semakin baik kinerja manajemen dalam mengelola perusahaan, sehingga perusahaan dengan tingkat profitabilitas yang rendah akan cenderung melakukan perataan laba.

H1: Diduga Financial Leverage dan Pertumbuhan Perusahaan berpengaruh terhadap Perataan Laba.

\subsubsection{Pengaruh pertumbuhan perusahaan terhadap perataan laba}

Pertumbuhan perusahaan dapat terjadi jika produktivitas dan tingkat keuntungan untuk pemegang saham meningkat. Kedua hal ini akan saling berhubungan. Meningkatnya produktivitas perusahaan akan meningkatkan laba perusahaan sehingga keuntungan untuk pemegang saham juga akan meningkat. dengan tingkat pertumbuhan yang tinggi akan cenderung melakukan perataan laba. investor hanya berminat pada perusahaan yang bertumbuh positif secara berkelanjutan.

H2: Diduga Pertumbuhan Perusahaan berpengaruh terhadap Perataan Laba

\subsubsection{Pengaruh financial leverage terhadap perataan laba}

perusahaan mendanai usahanya dengan membandingkan antara dana sendiri yang telah disetorkan dengan jumlah pinjaman dari para kreditur.perusahaan harus menyeimbangkan berapa utang yang layak diambil dan dari mana sumbersumber yang dapat dipakai untuk membayar utang. Leverage dalam penelitian ini diproksikan dengan debt to equity ratio yang diperoleh melalui total utang dibagi dengan total equity. Leverage menjadi tahapan dalam proses pembesaran laba perusahaan.

H3 : Diduga financial leverage berpengaruh positif terhadap perataan laba.

\subsubsection{Pengaruh Financial Leverage terhadap perataan laba yang dimoderasi profitabilitas.}

Variabel pemoderasi nantinya akan membuktikan apakah dapat mempengaruhi secara langsung antara variabel independen terhadap variabel dependen. Profitabilitas merupakan indicator untuk menilai kinerja atau kemampuan keuangan perusahaan dalam menghasilkan laba, rasio keuangan yang menggambarkan profitabilitas disebut rasio profitabilitas (profitability ratio) yaitu rasio yang mengukur kemampuan perusahaan memperoleh laba dalam hubungannya dengan penjualan, total aset dan modal sendiri. karena nilai leverage yang tinggi mencerminkan perusahaan tersebut terancam tidak sehat atau bangkrut, sehingga perusahaan tersebut cenderung akan menaikan atau meratakan laba agar tidak terjadi fluktuasi yang berlebihan agar tercermin kinerja perusahaan yang baik sehinggaperusahaan akan tetap dipercaya oleh pihak kreditur.

H4: Diduga Financial Leverage terhadap perataan laba yang dimoderasi profitabilitas.

\subsubsection{Pengaruh Pertumbuhan Perusahaan terhadap perataan laba yang dimoderasi profitabilitas}

perusahaan yang memiliki profitabilitas tinggi akan memiliki dorongan lebih kuat untuk menyebarluaskan informasi perusahaan. Sedangkan perusahaan 
dengan kinerja buruk cenderung menghindari melakukan pengungkapan melebihi yang diwajibkan (pengungkapan sukarela) karena mereka berusaha untuk menyembunyikan badnews. Sedangkan profitabilitas dan pertumbuhan perusahaan yang semakin tinggi merupakan variabel pemoderasi yang dapat memperkuat pengaruh Financial Leverage dan Pertumbuhan Perusahaan Terhadap Perataann Laba.

H4: Diduga Pertumbuhan Perusahaan terhadap perataan laba yang dimoderasi profitabilitas

\section{METODE PENELITIAN}

\subsection{Jenis Penelitian}

Penelitian ini adalah penelitian kualitatif yang bersifat deskriftif dan cenderung menggunakan analisis, yaitu penelitian yang menguji teori yang bersifat memilki hubungan dua variabel atau lebih melalui pengukuran variabelvariabel penelitian dengan angka atau analisis data bersifat sekunder bertujuan untuk menguji hipotesis.

\subsection{Variabel dan Pengukuran}

\subsubsection{Variabel Dependen}

Perataan laba merupakan tindakan yang dilakukan dengan sengaja untuk mengurangi varibilitas laba yang dilaporkan agar dapat mengurangi risiko pasar atas saham perusahaan, yang pada akhirnya dapat meningkatkan harga pasar perusahaan. Perataan Laba Indeks perataan laba $=(\mathrm{CV} \Delta \mathrm{I} / \mathrm{CV} \Delta \mathrm{S})$.

\subsubsection{Variabel Independen}

Financial leverage ratio ini merupakann salah satu rasio yang sangat penting karena berkaitan dengan masalahtrading on equity yang dapat memberikan pengaruh positif maupun negatif terhadap rentabilitas modal sendiri dari perusahaan tersebut. Pertumbuhan perusahaan merupakan faktor penentu struktur modal perusahaan, perusahaan yang tumbuh membutuhkan dana didalam menjalankan aktivitas operasinya mencakup pertumbuhan penjualan, laba, dan aktiva. Financial leverage $=$ Total Kewajiban $/$ Total Modal Sendiri.

\subsubsection{Variabel Moderasi}

Profitabilaitas merupakan salah satu kinerja bagi perusahaan, untuk menunjukkan kemampuan perusahaan dalam menghasilkan laba pada periode tertentu dengan menunjukkan tingkat

\subsection{Populasi dan Sampel}

Populasi yang digunakan dalam penelitian ini adalah perusahaan manufaktur pada sektor pulp \&kertas yang terdaftar di Bursa Efek Indonesia tahun 2007-2017. Sampel yang digunakan dalam penelitian ini diperoleh dengan metode purposive sampling yaitu populasi yang akan dijadikan sampel.

\subsection{Teknik Pengumpulan Data}

Metode pengumpulan data yang digunakan dalam penelitian ini adalah sebagai berikut : Studi Pustaka / Riset Kepustakaan (Library Research), dan dokumen. 


\subsection{Teknik Analisis}

Metode analisis data yang digunakan dalam penelitian ini adalah metode analisis data kuantitatif yang dinyatakan dengan angka-angka dan perhitungannya menggunakan metode statistik yang dibantu dengan program E-views versi 9. dilakukan analisis data sebagai berikut; Statistik Deskriptif, Uji Asumsi Klasik, Uji Regresi Linier Berganda, Uji Koefisien Determinasi (R2), Uji Hipotesis, Uji Statistik t (Uji Regresi Parsial), Uji statistik F (Uji Regresi Simultan).

\section{ANALISIS DATA DAN DISKUSI HASIL}

\subsection{Gambaran Umum Objek Penelitian}

Objek penelitian ini adalah perusahaan manufaktur sektor industri pulp \&kertas yang terdaftar di Bursa Efek Indonesia (BEI) mulai tahun 2007-2017. Fokus penelitian ini adalah untuk mengetahui pengaruh profitabiltas memoderasi financial leverage dan pertumbuhan perusahaan terhadap perataan laba.

\subsection{Deskripsi Sampel Penelitian}

sampel dipilih dengan purpose sampling dengan menggunakan kriteriakriteria : Perusahaan yang terdaftar diperusahaan manufaktur sektor pulp \&kertas yang terdaftar diBursa Efek Indonesia selama tahun 2007-2017, Perusahaan menerbitkan laporan keuangan tahunan secara lengkap selama periode 2007-2017, Tidak mengalami disleting dalam kurun waktu penelitian, yaitu periode 20072017. Berikut 7 perusahaan manufaktur sektor pulp \& kertas yang terdaftar di Bursa Efek Indonesia selama tahun 2007-2017 yang sesuai dengan purposive sampling :

\begin{tabular}{|l|l|l|}
\hline No & Nama Perusahaan & Kode Perusahaan \\
\hline 1. & Pt. Fajar Surya Wisesa Tbk & FASW \\
\hline 2. & PT. Indah Kiat Pulp \&Paper Tbk & INKP \\
\hline 3. & PT Toba Pulp Lestari Tbk & INRU \\
\hline 4. & PT Kertas Basuki Rachmat Indonesia Tbk & KBRI \\
\hline 5. & PT Kertas Basuki Rachmat Indonesia Tbk & KDSI \\
\hline 6. & PT. SUPARMA Tbk. & SPMA \\
\hline 7. & PT Pabrik Kertas Tjiwi Kimia Tbk & TKIM \\
\hline
\end{tabular}

\subsection{Analisis Deskriptif Variabel}

Uji statistik deskriptif berfungsi untuk memberikan deskripsi atau gambaran suatu data yang dilihat dari antara lain rata-rata (mean), standar deviasi, maksimum dan minimum, sum, range, kurtosis, dan skewness. Penelitian ini dilakukan untuk menganalisis pengaruh profitabilitas memoderasi Financial Leverage dan pertumbuhan perusahaan terhadap perataan laba pada perusahaan manufaktur sektor pulp \& kertas yang terdaftar di Bursa Efek Indonesia (BEI) dengan sampel sebanyak 7 perusahaan pada tahun 2007-2017. Berikut hasil olah 
data uji statistik deskriptif menggunakan E-views 9 dapat dilihat pada tabel dibawah ini :

\begin{tabular}{|c|c|c|c|c|}
\hline & PERATAAN & FINANCIAL & PERTUMBU... & PROFITABILI... \\
\hline Mean & $0.72727 \overline{3}$ & $0.18840 \overline{2}$ & 0.676257 & 0.026376 \\
\hline Median & 1.000000 & 0.167623 & 0.649055 & 0.026810 \\
\hline Maximum & 1.000000 & 1.000000 & 1.000000 & 0.090643 \\
\hline Minimum & 0.000000 & -0.185041 & 0.568377 & -0.044168 \\
\hline Std. Dev. & 0.448282 & 0.303110 & 0.110036 & 0.043159 \\
\hline Skewness & -1.020621 & 1.475334 & 2.232486 & -0.270343 \\
\hline Kurtosis & 2.041667 & 5.164285 & 7.112812 & 2.044047 \\
\hline Jarque-Bera & 16.31460 & 42.96140 & 118.2309 & 3.869851 \\
\hline Probability & 0.000287 & 0.000000 & 0.000000 & 0.144435 \\
\hline Sum & 56.00000 & 14.50692 & 52.07177 & 2.030973 \\
\hline Sum Sq. Dev. & 15.27273 & 6.982537 & 0.920206 & 0.141564 \\
\hline Observations & 77 & 77 & 77 & 77 \\
\hline
\end{tabular}

Perataan laba pada penelitian ini memiliki nilai mean sebesar 0.727273 nilai maximum 1.000000 dan nilai minimum sebesar 0.000000 sandar devisiasi 0,448282 nilai sum 56.00000 dan nilai skewness -1.020621 serta nilai kurtosis 2.041667. Financial Leverage pada penelitian ini memiliki nilai mean sebesar 0.188402 nilai maximum 1.000000 dan nilai minimum sebesar $-0,185041$ sandar devisiasi 0,303110 nilai sum 14.50692 dan nilai skewness 1.475334 serta nilai kurtosis 5.164285. sedangkan pada perumbuhan perusahaan pada penelitian ini nilai mean sebesar 0.676257 nilai maximum 1.000000 dan nilai minimum sebesar 0.568377 standar devisiasi 0.110036 nilai sum 52.07177 dan nilai skewness 2.232486 serta nilai kurtosis 7.1128. Sedangkan pada profitabilitas sebagai variabel moderasi untuk nilai mean sebesar 0.026376 nilai maksimum 0.090643 untuk nilai minimum sebesar -0.044168 sandar devisiasi 0.043159 nilai sum 2.030973 dan nilai skewness -0.270343 serta nilai kurtosis 2.044047 .

\subsection{Hasil Pengolahan Data}

\subsubsection{Uji Asumsi Klasik}

Pengujian Asumsi Klasik digunakan untuk mengetahui ketepatan dalam data. Dalam penelitian ini uji asumsi klasik yang digunakan adalah uji Normalitas, Uji Multikolinearitas, Uji Autokorelasi, dan Uji Heterokedastisitas yang diolah dengan software E-views 9 yang hasilnya sebagai berikut:

\subsubsection{Uji Normalitas}

Berikut hasil Uji Normalitas yang bertujuan untuk mengetahui dalam model variable independen dan dependen berdistribusi normal.
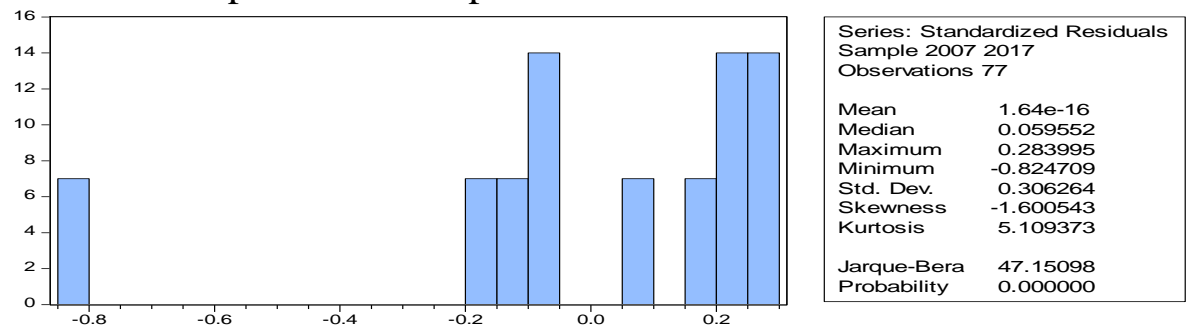
nilai Jarque Beta sebesar 47.15098, dengan nilai probabilitas 0.000000 dimana nilai tersebut lebih besar dari $\alpha=0,05(5 \%),(0.000000>0,05)$ dengan demikian dapat disimpulkan bahwa model regresi layak dipakai Karena memenuhi asumsi normalitas.

\subsubsection{Uji Multikolinieritas}

Berikut hasil Uji Multikolinieritas antara variable Independen :

\begin{tabular}{|l|l|l|l|l|}
\hline & XM & Y & X2 & X1 \\
\hline XM & 1.000000 & -0.154075 & -0.327630 & 0.173243 \\
\hline Y & -0.154075 & 1.000000 & -0.516211 & -0.614030 \\
\hline X2 & -0.327630 & -0.516211 & 1.000000 & 0.211589 \\
\hline X1 & 0.173243 & -0.614030 & 0.211589 & 1.000000 \\
\hline
\end{tabular}

Pada tabel diatas menunjukan nilai untuk setiap variabel independen Finanncial Leverage (X1) sebesar 1.000000, Pertumbuhan Perusahaan (X2) sebesar 1.000000. dimana masing-masing variabel independen, tidak terdapat nilai koefisien korelasi yang lebih besar dari 0,800 sehingga uji ini menemukan tidak terjadinya multikolinieritas antara variabel independen.

\subsubsection{Uji Autokorelasi}

Uji Autokorelasi bertujuan untuk mengetahui ada tidaknya penyimpangan korelasi antara anggota sampel yang diurutkan berdasarkan waktu, seperti hasil uji autokorelasi dibawah ini :

Breusch-Godfrey Serial Correlation LM Test:

\begin{tabular}{llll}
\hline \hline F-statistic & 0.587514 & Prob. F(2,72) & 0.5583 \\
Obs*R-squared & 1.236449 & Prob. Chi-Square(2) & 0.5389 \\
\hline \hline
\end{tabular}

Test Equation:

Dependent Variable: RESID

Method: Least Squares

Date: 04/26/19 Time: 13:35

Sample: 20072083

Included observations: 77

Presample missing value lagged residuals set to zero.

\begin{tabular}{crrrr}
\hline \hline \multicolumn{1}{c}{ Variable } & Coefficient & Std. Error & t-Statistic & Prob. \\
\hline \hline C & 0.000175 & 0.179960 & 0.000974 & 0.9992 \\
X1 & -0.005463 & 0.063905 & -0.085481 & 0.9321 \\
X2 & 0.000829 & 0.290617 & 0.002852 & 0.9977 \\
RESID(-1) & 0.126987 & 0.118748 & 1.069382 & 0.2885 \\
RESID(-2) & 0.008663 & 0.122349 & 0.070808 & 0.9437 \\
\hline \hline R-squared & 0.016058 & Mean dependent var & $7.79 E-17$ \\
Adjusted R-squared & -0.038606 & S.D. dependent var & 0.485699 \\
S.E. of regression & 0.494986 & Akaike info criterion & & 1.494155 \\
Sum squared resid & 17.64078 & Schwarz criterion & 1.646350
\end{tabular}




\begin{tabular}{lrlr} 
Log likelihood & -52.52497 & Hannan-Quinn criter. & 1.555032 \\
F-statistic & 0.293757 & Durbin-Watson stat & 1.966154 \\
Prob(F-statistic) & 0.881119 & \\
\hline \hline
\end{tabular}

Dari uji autokorelasi pada tabel 4.6 dengan metode least squares didapat hasil Durbin-Watson stat sebesar 1.966154 yang mana nilai tersebut berada diantara kriteria $(1,55-2,45)$ sehingga dengan ketentuan pada tabel pedoman interprestasi uji Durbin Watson maka model regresi ini dengan keterangan tidak ada autokorelasi.

\subsubsection{Uji Heterokedastisitas}

Adapun hasil Uji Heterokedastisitas dalam penelitian ini adalah sebagai berikut :

\begin{tabular}{|c|c|c|c|c|}
\hline $\begin{array}{l}\text { F-statistic } \\
\text { Obs*R-squared } \\
\text { Scaled explained SS }\end{array}$ & $\begin{array}{l}1.122636 \\
2.267498 \\
0.411629 \\
\end{array}$ & \multicolumn{2}{|c|}{$\begin{array}{l}\text { Prob. F(2,74) } \\
\text { Prob. Chi-Square(2) } \\
\text { Prob. Chi-Square(2) }\end{array}$} & $\begin{array}{l}0.3309 \\
0.3218 \\
0.8140 \\
\end{array}$ \\
\hline \multicolumn{5}{|c|}{$\begin{array}{l}\text { Test Equation: } \\
\text { Dependent Variable: ARESID } \\
\text { Method: Least Squares } \\
\text { Date: 06/24/19 Time: } 13: 17 \\
\text { Sample: } 20072083 \\
\text { Included observations: } 77 \\
\end{array}$} \\
\hline Variable & Coefficient & Std. Error & $\mathrm{t}$-Statis tic & Prob. \\
\hline $\begin{array}{l}\mathrm{C} \\
\times 1 \\
\times 2\end{array}$ & $\begin{array}{r}0.458423 \\
0.023846 \\
-0.000220\end{array}$ & $\begin{array}{l}0.046096 \\
0.016057 \\
0.074362\end{array}$ & $\begin{array}{r}9.945060 \\
1.485138 \\
-0.002965\end{array}$ & $\begin{array}{l}0.0000 \\
0.1418 \\
0.9976\end{array}$ \\
\hline $\begin{array}{l}\text { R-squared } \\
\text { Adjusted R-squared } \\
\text { S.E. of regression } \\
\text { Sum squared resid } \\
\text { Log likelihood } \\
\text { F-statistic } \\
\text { Prob(F-statistic) }\end{array}$ & $\begin{array}{l}0.029448 \\
0.003217 \\
0.127045 \\
1.194390 \\
51.13928 \\
1.122636 \\
0.330899\end{array}$ & \multicolumn{2}{|c|}{$\begin{array}{l}\text { Mean dependent var } \\
\text { S.D. dependent var } \\
\text { Akaike info criterion } \\
\text { Schwarz criterion } \\
\text { Hannan-Quinn criter. } \\
\text { Durbin-Watson stat }\end{array}$} & $\begin{array}{r}0.465680 \\
0.127250 \\
-1.250371 \\
-1.159054 \\
-1.213845 \\
1.902887\end{array}$ \\
\hline
\end{tabular}

Dari hasil table di atas dapat dilihat bahwa heterokedasticity test glester, nilai probabilitas Obs*R-squared sebesar 2.267498 dimana nilai tersebut lebih besar dari $\alpha=5 \%(2.267498>0,05)$. Ini membuktikan bahwa model regresi tersebut menujukan tidak terjadi heterokedastisitas.

\subsubsection{Pengujian Model Regresi Data Panel}

\subsubsection{Uji Chow}

Berikut ini merupakan hasil Uji Chow Financial Leverage dan Pertumbuhan Perusahaan terhadap Income smoothing, sebagai berikut : 
Redundant Fixed Effects Tests Equation: Untitled

Test cross-section fixed effects

\begin{tabular}{llrr}
\hline \hline Effects Test & Statistic & d.f. & Prob. \\
\hline \hline Cross-section F & 0.000000 & $(6,68)$ & 1.0000 \\
Cross-section Chi-square & 0.000000 & 6 & 1.0000 \\
\hline \hline
\end{tabular}

Cross-section fixed effects test equation:

Dependent Variable: $Y$

Method: Panel Least Squares

Date: 04/22/19 Time: 15:42

Sample: 20072017

Periods included: 11

Cross-sections included: 7

Total panel (balanced) observations: 77

\begin{tabular}{lrlrr}
\hline \hline \multicolumn{1}{c}{ Variable } & Coefficient & Std. Error & t-Statistic & Prob. \\
\hline \hline C & 1.988641 & 0.223020 & 8.916881 & 0.0000 \\
X1 & -0.781570 & 0.120178 & -6.503422 & 0.0000 \\
\multicolumn{1}{c}{-1.647479} & 0.331047 & -4.976567 & 0.0000 \\
\hline \hline R-squared & 0.533246 & Mean dependent var & 0.727273 \\
Adjusted R-squared & 0.520631 & S.D. dependent var & 0.448282 \\
S.E. of regression & 0.310375 & Akaike info criterion & 0.536110 \\
Sum squared resid & 7.128612 & Schwarz criterion & 0.627427 \\
Log likelihood & -17.64024 & Hannan-Quinn criter. & 0.572636 \\
F-statistic & 42.27082 & Durbin-Watson stat & 1.579480 \\
Prob(F-statistic) & 0.000000 & & & \\
\hline \hline
\end{tabular}

Berikut Hasil Uji Chow Financial Leverage dan Pertumbuhan Perusahaan berpengaruh terhadap perataan laba yang dimoderasi profitabilitas, sebagai berikut:

Redundant Fixed Effects Tests

Equation: Untitled

Test cross-section fixed effects

\begin{tabular}{llrr}
\hline \hline Effects Test & Statistic & d.f. & Prob. \\
\hline \hline Cross-section F & 0.000000 & $(6,66)$ & 1.0000 \\
Cross-section Chi-square & 0.000000 & 6 & 1.0000 \\
\hline \hline
\end{tabular}

Cross-section fixed effects test equation:

Dependent Variable: $Y$

Method: Panel Least Squares

Date: 06/24/19 Time: 12:16

Sample: 20072017

Periods included: 11

Cross-sections included: 7

Total panel (balanced) observations: 77

\begin{tabular}{crlrr}
\multicolumn{1}{c}{ Variable } & Coefficient & Std. Error & t-Statistic & Prob. \\
\hline \hline C & 2.299059 & 0.243020 & 9.460352 & 0.0000 \\
X1 & -0.579465 & 0.195255 & -2.967741 & 0.0041 \\
X2 & -2.033193 & 0.350523 & -5.800452 & 0.0000 \\
X1_X3VM & -3.383157 & 5.122609 & -0.660436 & 0.5111 \\
X2_X3VM & -3.881475 & 1.343416 & -2.889258 & 0.0051 \\
\hline \hline & 0.587084 & Mean dependent var & 0.727273 \\
R-squared & 0.564145 & S.D. dependent var & 0.448282 \\
Adjusted R-squared & 0.295953 & Akaike info criterion & 0.465498 \\
S.E. of regression & 6.306348 & Schwarzcriterion & 0.617694 \\
Sum squared resid & -12.92169 & Hannan-Quinn criter. & 0.526375 \\
Log likelihood & 25.59244 & Durbin-Watson stat & 2.147495 \\
F-statistic & 0.000000 & & & \\
Prob(F-statistic) & & & &
\end{tabular}


Dari table diatas dapat dilihat hasil Uji Chow pada Financial Leverage, Pertumbuhan Perusahaan Terhadap Perataan Laba bahwa nilai probabilitas (prob) cross sections F-statistic adalah $1.0000>0,05$ ditentukan sebagai nilai signifikan $\alpha$, maka H0 diterima dan H1 ditolak. Sehingga dapat disimpulkan bahwa model yang paling tepat adalah common effect (Pool Least Square).

\subsubsection{Uji Hausman}

Berikut ini merupakan Uji Hausman Financial Leverage, Pertumbuhan Perusahaan Terhadap Perataan Laba dan Uji Hausman Financial Leverage, Pertumbuhan Perusahaan melalui Profitabilitas Terhadap Perataan Laba,

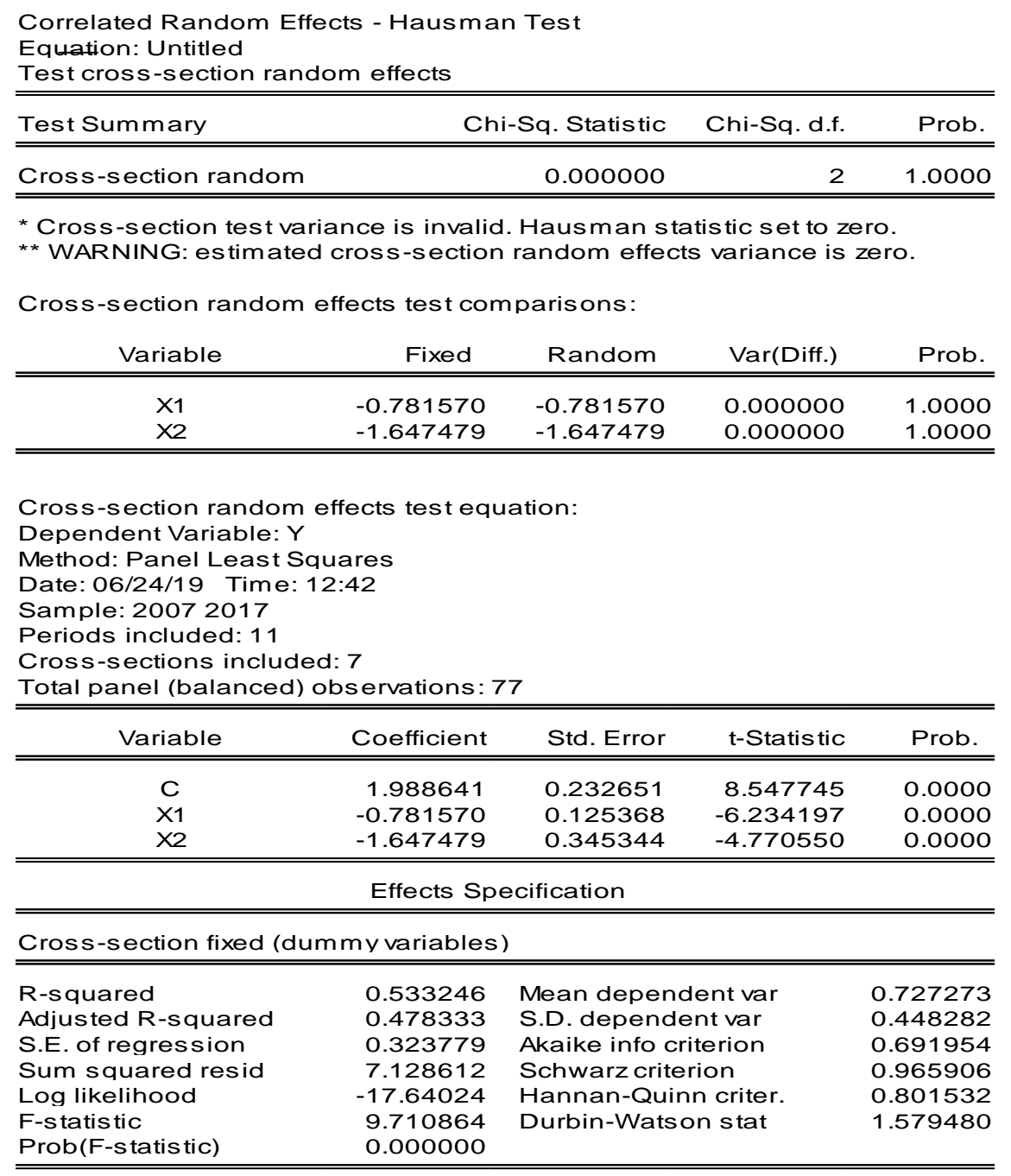

Uji Hausman Financial Leverage, Pertumbuhan Perusahaan melalui Profitabilitas Terhadap Perataan Laba : 


\begin{tabular}{|c|c|c|c|c|}
\hline \multicolumn{5}{|c|}{$\begin{array}{l}\text { Correlated Random Effects - Hausman Test } \\
\text { Equation: Untitled } \\
\text { Test cross-section random effects }\end{array}$} \\
\hline Test Summary & \multicolumn{2}{|c|}{ Chi-Sq. Statistic } & Chi-Sq. d.f. & Prob. \\
\hline Cross-section random & & 0.000000 & 4 & 1.0000 \\
\hline \multirow{2}{*}{\multicolumn{5}{|c|}{$\begin{array}{l}\text { * Cross-section test variance is invalid. Hausman } \\
\text { ** WARNING: estimated cross-section random ef } \\
\text { Cross-section random effects test comparisons: }\end{array}$}} \\
\hline & & & & \\
\hline Variable & Fixed & Random & $\operatorname{Var}($ Diff.) & Prob. \\
\hline $\mathrm{X}_{1}$ & -0.579465 & -0.579465 & -0.000000 & \\
\hline$\times 2$ & -2.033193 & -2.033193 & -0.000000 & \\
\hline X1_X3VM & -3.383157 & -3.383157 & -0.000000 & \\
\hline$\times 2-\times 3 \mathrm{VM}$ & -3.881475 & -3.881475 & 0.000000 & 1.0000 \\
\hline
\end{tabular}

Cross-section random effects test equation:

Dependent Variable: Y

Method: Panel Least Squares

Date: 06/24/19 Time: 12:30

Sample: 20072017

Periods included: 11

Cross-sections included: 7

Total panel (balanced) observations : 77

\begin{tabular}{crrrr}
\hline \hline Variable & Coefficient & Std. Error & t-Statistic & Prob. \\
\hline \hline C & 2.299059 & 0.253827 & 9.057597 & 0.0000 \\
X1 & -0.579465 & 0.203937 & -2.841396 & 0.0060 \\
X2 & -2.033193 & 0.366110 & -5.553510 & 0.0000 \\
X1_X3VM & -3.383157 & 5.350390 & -0.632320 & 0.5294 \\
X2_X3VM & -3.881475 & 1.403152 & -2.766254 & 0.0073 \\
\hline \hline
\end{tabular}

Cross-section fixed (dummy variables)

\begin{tabular}{lrll}
\hline \hline R-squared & 0.587084 & Mean dependent var & 0.727273 \\
Adjusted R-squared & 0.524521 & S.D. dependent var & 0.448282 \\
S.E. of regression & 0.309113 & Akaike info criterion & 0.621343 \\
Sum squared resid & 6.306348 & Schwarz criterion & 0.956172 \\
Log likelihood & -12.92169 & Hannan-Quinn criter. & 0.755271 \\
F-statistic & 9.383895 & Durbin-Watson stat & 2.147495 \\
Prob(F-statistic) & 0.000000 & & \\
\hline \hline
\end{tabular}

hasil Uji Hausman bahwa nilai Probabilitas (prob) cross-section F adalah $1.0000>0,05$ (syarat signifikansi $\alpha$ ), maka H0 diterima dan H1 ditolak dalam hal ini menggunakan pendekatan random effect. Dari kedua Model Regresi Data Panel yang digunakan yaitu Uji Chow dan Uji Hausman menunjukkan hasil yang konsisten namun dikarenakan dari Uji tersebut lebih dominan atau lebih signifikan yaitu random effect model regression maka dapat disimpulkan model regresi yang digunakan adalah Random Effect Model.

\subsection{Hasil Analisa Data}

\subsubsection{Pengujian Koefisien Determinasi dan Persamaan Regresi}

\subsubsection{1 koefisien Determinasi}

Koefisien determinasi Financial Leverage dan Pertumbuhan Perusahaan dapat dillihat pada tabel 4.10 dengan besarnya angka Adjusted R-Square (R2) adalah 0.524521 hal ini menunjukkan bahwa persentase memberikan pengaruh 
variabel independen terhadap variabel dependen sebesar 52\% sedangkan sisanya $48 \%$ lainnya dipengaruhi oleh faktor lain diluar dari model regresi ini.

\subsubsection{Persamaan Model Regresi Financial Leverage dan Pertumbuhan Perusahaan dimoderasi Profitabilitas terhadap Perataan Laba}

Dari hasil persamaan regresi berganda diatas dapat dianalisis dengan pernyataan sebagai berikut :

1. Konstanta regresi 1.988 menyatakan bahwa jika variabel bebas Financial Leverage dan Pertumbuhan Perusahaan dianggap nol, maka nilai Perataan laba sebesar 74.38.

2. Konstanta regresi Financial Leverage sebesar-0,781 menyatakan bahwa setiap penambahan Financial Leverage sebesar 1 maka akan menurunkan perataan laba sebesar $-0,781$.

3. Konstanta regresi pertumbuhan perusahaan sebesar $(-1,647)$ menyatakan bahwa setiap penambahan pertumbuhan perusahaan sebesar 1 maka akan menurunkan nilai perataan laba sebesar $(-1,647)$.

\subsubsection{Uji Parsial (Uji t)}

Apabila nilai $\mathrm{t}_{\text {hitung }}>\mathrm{t}_{\text {tabel, }}$ maka Ho ditolak dan dapat disimpulkan bahwa variabel independen berpengaruh secara signifikan terhadap variabel dependen. Dan sebaliknya apabila $\mathrm{t}_{\text {hitung }}<\mathrm{t}_{\text {tabel }}$, maka Ho diterima dan dapat disimpulkan bahwa variabel dependen, apabila nilai probabilitas (prob) $\mathrm{t}_{\text {hitung }}$ ditunjukkan pada (prob) lebih kecil dari tingkat kesalahan $(\alpha)$ yaitu sebesar 0,05 maka dapat diasumsikan bahwa variabel bebas berpengaruh secara signifikan terhadap variabel terikat. Sedangkan apabila nilai probabilitas (prob) t hitung $>$ kesalahan $(\alpha)$ sebesar 0,05 maka dapat diasumsikan

\subsubsection{Pengaruh Financial Leverage terhadap Perataan Laba}

Berdasarkan tabel 4.9 maka diperoleh hasil $t_{\text {hitung }}$ Financial Leverage adalah sebesar-6.234197, $\mathrm{t}$ tabel $=1,99254$ sehingga $\mathrm{t}_{\text {hitung }}>\mathrm{t}_{\text {tabel }}(-6.234197>1,99254)$, hal ini diperkuat dengan nilai probability lebih kecil dari signifikansi atau $(0.0000<0,05)$. jadi $\mathrm{H}_{0}$ ditolak dan $\mathrm{H}_{1}$ diterima sehingga dapat disimpulkan bahwa Financial Leverage berpengaruh dan signifikan terhadap perataan laba berarti apabila terjadi kenaikan Financial Leverage sebesar $623.4 \%$ maka perataan laba akan semakin meningkat sebesar 623,4\%.

\subsubsection{Pengaruh Pertumbuhan Perusahaan terhadap Perataan Laba}

Berdasarkan tabel 4.9 maka diperoleh hasil $t$ hitung Financial Leverage adalah sebesar $-4,770550, \mathrm{t}$ tabel $=1$,99254sehingga $\mathrm{t}$ hitung $\mathrm{t}$ tabel $\quad(-$ $4,770550>1,99254)$, hal ini diperkuat dengan nilai probability lebih kecil dari signifikansi atau $(0.0000<0,05)$. jadi $\mathrm{H}_{0}$ ditolak dan $\mathrm{H}_{1}$ diterima sehingga dapat disimpulkan bahwa pertumbuhan perusahaan berpengaruh dan signifikan terhadap perataan laba berarti apabila terjadi kenaikan pertumbuhan perusahaan sebesar $477 \%$ maka perataan laba akan semakin meningkat sebesar $477 \%$. 


\subsubsection{Pengaruh Financial Leverage terhadap Perataan Laba yang dimoderasi Profitabilitas}

Berdasarkan tabel 4.9 maka diperoleh hasil $t_{\text {hitung }}$ Financial Leverage adalah sebesar -2,841396, $\mathrm{t}$ tabel $=1,99254$ sehingga $\mathrm{t}_{\text {hitung }}>\mathrm{t}_{\text {tabel }}(-2,841396>1,99254)$, hal ini diperkuat dengan nilai probability lebih kecil dari signifikansi atau $(0.0000<0,05)$. jadi $\mathrm{H}_{0}$ ditolak dan $\mathrm{H}_{1}$ diterima sehingga dapat disimpulkan bahwa Financial Leverage berpengaruh dan signifikan terhadap perataan laba berarti apabila terjadi kenaikan Financial Leverage sebesar $284 \%$ maka perataan laba akan semakin meningkat sebesar $284 \%$.

\subsubsection{Pengaruh Pertumbuhan Perusahaan terhadap Perataan Laba yang dimoderasi Profitabilitas}

Berdasarkan tabel 4.10 maka diperoleh hasil $t$ hitung Financial Leverage adalah sebesar -5,553510, $\mathrm{t}$ tabel $=1$,99254sehingga $\mathrm{t}$ hitung $>\mathrm{t}$ tabel ($5,553510>1,99254)$, hal ini diperkuat dengan nilai probability lebih kecil dari signifikansi atau $(0.0000<0,05)$. jadi $\mathrm{H}_{0}$ ditolak dan $\mathrm{H}_{1}$ diterima sehingga dapat disimpulkan bahwa pertumbuhan perusahaan berpengaruh dan signifikan terhadap perataan laba berarti apabila terjadi kenaikan pertumbuhan perusahaan sebesar $555 \%$ maka perataan laba akan semakin meningkat sebesar $555 \%$.

\subsubsection{Uji secara simultan (uji F)}

Berdasarkan tabel 4.10 diatas, nilai $F_{\text {hitung }}$ yaitu sebesar 9.383895 dan $\mathrm{F}$ table dengan tingkat signifikan $=5 \%$ dan df1 $(\mathrm{k}-1)=(3-1)=2$ dan df2 $(\mathrm{n}-\mathrm{k})=(77-$ $3)=74$ didapat $\mathrm{F}_{\text {tabel }} 3,12$ dengan demikian $\mathrm{F}_{\text {hitung }}>\mathrm{f}_{\text {tabel }}(9,383895>3,12)$ dan ditunjukkan juga nilai probabilitasnya yang lebih kecil dari tingkat signifikan 0,05 $(0.000<0,05)$, jadi $\mathrm{H}_{0}$ ditolak dan $\mathrm{H}_{1}$ diterima, dan dapat disimpulkan bahwa Financial Leverage dan Pertumbuhan Perusahaan yang dimoderasi Profitabilitas berpengaruh secara simultan terhadap Perataan Laba. Yang artinya apabila terjadi kenaikan nilai sebesar $95 \%$ pada Financial Leverage dan Pertumbuhan Perusahaan maka nilai perataan laba akan semakin meningkat sebesar $95 \%$.

\section{6 pembahasan}

\subsubsection{Pengaruh Financial Leverage berdasarkan Return On asset (ROA) terhadap Perataan Laba (Income Smoothing)}

persamaan regresi sederhana pada model analisis untuk hipotesis pertama menyatakan bahwa hasil uji t (Uji parsial) dan uji F (Uji simultan) memberikan informasi bahwa Financial Leverage berasarkan Return On Assets (ROA) berpengaruh positif dan signifikan terhadap perataan laba (Income Smoothing). terjadi kenaikan Financial Leverage sebesar $623.4 \%$ maka perataan laba akan semakin meningkat sebesar $623,4 \%$.

\subsubsection{Pengaruh Pertumbuhan Perusahaan Berdasarkan Return On Asset Equity (ROE) terhadap Perataan Laba (Income Smoothing)}


pada model analisis untuk hipotesis kedua menyatakan bahwa hasil uji t (Uji parsial) dan uji $\mathrm{F}$ (Uji simultan) memberikan informasi dengan nilai probability lebih kecil dari signifikansi dapat disimpulkan bahwa pertumbuhan perusahaan berpengaruh dan signifikan terhadap perataan laba berarti apabila terjadi kenaikan pertumbuhan perusahaan sebesar $477 \%$ maka perataan laba akan semakin meningkat sebesar $477 \%$.

\subsubsection{Pengaruh Financial Leverage terhadap Perataan Laba yang dimoderasi Profitabilitas}

dapat disimpulkan bahwa Financial Leverage dan Pertumbuhan Perusahaan yang dimoderasi Profitabilitas berpengaruh secara simultan terhadap Perataan Laba. Yang artinya apabila terjadi kenaikan nilai sebesar 95\% pada Financial Leverage dan Pertumbuhan Perusahaan maka nilai perataan laba akan semakin meningkat sebesar $95 \%$.

\subsubsection{Pengaruh Pertumbuhan Perusahaan terhadap Perataan Laba yang dimoderasi Profitabilitas}

dapat disimpulkan bahwa pertumbuhan perusahaan berpengaruh dan signifikan terhadap perataan laba yang dimoderasi dengan Profitabilitas berarti apabila terjadi kenaikan pertumbuhan perusahaan sebesar $555 \%$ maka perataan laba akan semakin meningkat sebesar 555\%

\subsubsection{Pengaruh Financial Leverage, Pertumbuhan Perusahaan yang dimoderasi Profitabilitas terhadap Perataan Laba}

dapat disimpulkan bahwa Financial Leverage dan Pertumbuhan Perusahaan yang dimoderasi Profitabilitas berpengaruh secara simultan terhadap Perataan Laba. Yang artinya apabila terjadi kenaikan nilai sebesar 95\% pada Financial Leverage dan Pertumbuhan Perusahaan maka nilai perataan laba akan semakin meningkat sebesar $95 \%$.

\section{KESIMPULAN}

dengan menggunakan aplikasi eviews versi 9 dan untuk menjawab rumusan masalah maka penulis memberikan kesimpulan sebagai berikut:

1. Disimpulkan bahwa Financial Leverage berasarkan Return On Assets (ROA) berpengaruh positif dan signifikan terhadap perataan laba (Income Smoothing).

2. Disimpulkan bahwa pertumbuhan perusahaan berpengaruh dan signifikan terhadap perataan laba.

3. Disimpulkan bahwa Financial Leverage dan Pertumbuhan Perusahaan yang dimoderasi Profitabilitas berpengaruh secara simultan terhadap Perataan Laba.

4. Disimpulkan bahwa pertumbuhan perusahaan berpengaruh dan signifikan terhadap perataan laba dengan dimoderasi Profitabilitas.

5. disimpulkan bahwa Financial Leverage dan Pertumbuhan Perusahaan yang dimoderasi Profitabilitas berpengaruh secara simultan terhadap Perataan Laba. 


\section{DAFTAR PUSTAKA}

Follet, Mary Parker. (1999). Visionary Leadership and Strategic Management. MCB University Press. Woman in Management Review Volume 14 Number 7.

George R. Terry. (2000). Prinsip-Prinsip Manajement, (edisi bahasa Indonesia), PT.Bumi Aksara, Bandung.

Gitman, Lawrence J. \& Chad J. Zutter. (2012). Principles of Manageria lFinance, 13 th Edition. Pearson International Edition, Global Edition, England.

Hani, T . Handoko. (2011). Manajement Edisi 2. Cetakan Kedelapan Belas, BPFE, Yogjakarta.

Hunger, David dan Thomas L. Wheelen. (2003). Manajement Strategi. Penerbit Andi, Yogyakarta.

IAI. (1994). Pernyataan Standar Akuntansi Keuangan (PSAK) No.23 PEDAPATA. IAI, Jakarta.

Kasmir. (2013). Bank dan Lembaga Keuangan Lainnya. Cetakan ke-12, Penerbit Raja grafindo Persada, Jakarta.

Kieso , D.E., Weygandt, J.J., \&Warfield, T.D. (2011). Intermediate Accounting Volume 1 IFRS Edition. Wiley,United States of America.

Ramadi, Adha dan Sutjipto Ngumar. (2015). Perhitungan Pendapatan dan Beban Untuk Mengukur Kinerja Keuangan Perusahaan Jasa. Volume 4, No. 11, https://ejournal.stiesia.ac.id/jira/article/view/1106.

Rismansyah dan Nurlaili Safitri. (2015). Analisis Pengakuan Pendapatan dan Beban Pada PT Wahana Bumi Riau Cabang Palembang. Volume 12,No.2,http://kurikulum.univpgripalembang.ac.id/e_jurnal/index.php/Ekon omika/article/view/288, Juli 2015.

Sabardi, Agus. (2012). Manajemen Pengantar. Cetakan Kedua, Gramedia, Jakarta.

Stice E.K., Stice J.D., dan Skousen, K.F. (2010). Intermediate Accounting. edisi 15, buku1,Salemba Empat, Jakarta.

Stoner, James A.F., 2006. Manajemen. Jilid I, Edisi Keenam, Salemba Empat, Jakarta.

Sugiyono. (2009). Metode Penelitian Kuantitatif, Kualitatif dan $R \& D$. Cetakan ke8, Penerbit Alfabeta, Bandung.

Sutrisno. (2014). Manajemen Keuangan Teori Konsep \& Aplikasi. Ekonisia Fakultas Ekonomi UII, Yogyakarta.

Welsch, Hilton, Gordon. (2011). Anggaran, Perencanaan dan Pengendalian Laba. BPFE, Yogyakarta. 